\section{Resenha}

Review

PODGORNY, Irina (coord.)

\title{
Diccionario histórico de las ciencias de la Tierra en Argentina
}

\author{
Rosario: Prohistoria Ediciones; La Plata: Museo de la \\ Plata; Buenos Aires: CONICET, 2016. 400 p.; $23 \times 16 \mathrm{~cm}$. \\ ISBN 978-987-3864-27-8.
}

\author{
SILVIA FIGUEIRÔA \\ Universidade Estadual de Campinas | UNICAMP
}

Em 140 verbetes, os 73 autores, coordenados pela pesquisadora Irina Podgorny que já acumula larga expertise, buscam dar conta de quase 200 anos de história das ciências da Terra na Argentina. Não é uma tarefa fácil, mas foi muito bem executada pelo coletivo, pois o mergulho em suas páginas permite construir um panorama argentino rico e diversificado dessas ciências, especialmente no século XIX, tarefa facilitada pelas remissivas, pela bibliografia indicada após cada texto e pelas ilustrações (em preto e branco). Este, aliás, é um problema (menor) que uma eventual publicação digital poderia sanar, ao menos no caso dos mapas e das paisagens, que perdem resolução - e, portanto, capacidade de informação - quando não estão reproduzidos em suas cores originais.

Uma introdução geral sobre a constituição da Geologia como ciência prepara o leitor não especialista para o que encontrará ao longo do livro, cujo objetivo explícito é "pensar la historia más allá y más acá de los individuos, las instituciones y la organización actual de las ciências de la Tierra" (p. 27). No entanto, mesmo os especialistas aprendem muito com essa obra, que adquiriu contornos bastante originais ao radicalizar o tema central (Ciências da Terra) e incorporar verbetes sobre paisagens representativas de cada região ilustrando problemas geológicos. Por exemplo: Aconcagua, Campo del Cielo, Canal Beagle, Cataratas del Iguazú, Glaciar Perito Moreno, Quebrada de Humahuaca, dentre outras.

0 conjunto de entradas subdivide-se nos seguintes grupos: Instituciones (21 verbetes), Problemas, métodos, modelos (24 verbetes), Disciplinas (14 verbetes), Minerales y rocas de uso económico/Geología y medicina (10 verbetes), Instrumentos (17 verbetes), Biografías (41 verbetes) e Paisajes (23 verbetes). Em todos os subgrupos notam-se as peculiaridades e especificidades da Argentina: além das já mencionadas paisagens, foram contempladas disciplinas que se desenvolveram ali mais do que em outros locais, personagens menos conhecidos por uma pretensa 'história geral das ciências' (mas não menos importantes na construção cotidiana dos processos científicos e na institucionalização das Geociências em território argentino), participações em exposições universais, ou mesmo 'minerais argentinos'. Em consonância com esse espírito, a obra é dedicada a Horacio Camacho (1922-2015), um pioneiro da História das (Geo)Ciências na Argentina.

Há ausências deliberadas, como a omissão de entradas sobre Charles Darwin e Hermann Burmeister, posto que já por demais conhecidos. Entretanto, aprende-se muito com o Diccionario, que serve tanto aos que trabalham sobre este país quanto aos que investigam outros temas, cujos desdobramentos se entrelaçam com a rede de instituições e pesquisadores em ação nessa região da América do Sul. 